\title{
Quantification of MET and hepatocyte growth factor/scatter factor expression in colorectal adenomas, carcinomas and non- neoplastic epithelia by quantitative laser scanning microscopy
}

\author{
STEPHAN E. BALDUS ${ }^{1}$, ERIC J. KORT ${ }^{2}$, PETER SCHIRMACHER ${ }^{3}$, HANS P. DIENES ${ }^{4}$ and JAMES H. RESAU ${ }^{2}$ \\ ${ }^{1}$ Institute of Pathology, University of Duesseldorf, Duesseldorf, Germany; ${ }^{2}$ Van Andel Research Institute (VARI), \\ Grand Rapids, MI, USA; ${ }^{3}$ Institute of Pathology, University of Heidelberg, Heidelberg; \\ ${ }^{4}$ Institute of Pathology, University of Cologne, Cologne, Germany
}

Received January 16, 2007; Accepted February 26, 2007

\begin{abstract}
Hepatocyte growth factor (HGF)-MET signalling in cancer biology has been well characterized in multiple organ systems. Numerous investigations have described an up-regulation of c-met mRNA in human colorectal adenomas and carcinomas. However, a quantitative immunohistochemical analysis of MET and HGF protein levels in tumor tissues has not been reported previously. Formalin-fixed and paraffinembedded tissues from 41 colorectal adenomas and 49 colorectal carcinomas were characterized by immunofluorescent staining using HGF- and MET-specific antibodies. The immunoreactivity was evaluated by confocal laser scanning microscopy, computer-based image analysis and appropriate statistical tests. Normal colorectal mucosa, adenomas and carcinomas exhibited comparable levels of MET and HGF proteins. MET expression in carcinomas, although statistically not significant, demonstrated a tendency to correlate with the grade of differentiation. Correlations of MET and HGF with other clinico-pathological variables including the extent of the mucinous component and the pTNM stage were not observed. The ratio of HGF in carcinoma vs. non-neoplastic tissue was significantly different between high and low carcinoma stage. Alterations of absolute levels of MET and HGF protein during the colorectal adenoma-carcinoma sequence were not significant. The presumed role of MET-HGF interactions in large bowel carcinogenesis may therefore be a result of or depend upon other regulatory factors involved in METmediated signalling pathways.
\end{abstract}

Correspondence to: Professor Stephan E. Baldus, Institute of Pathology, University of Duesseldorf, Moorenstrasse 5, D-40225 Duesseldorf, Germany

E-mail: stephan.baldus@uni-duesseldorf.de

Key words: MET, hepatocyte growth factor, colon cancer, confocal microscopy, image analysis

\section{Introduction}

Colon carcinoma is one of the most common malignant tumors in the industrialized countries (1). The majority of these carcinomas arise in pre-existing adenomas via the so-called adenoma-carcinoma sequence (2) but multiple pathways of development have been proposed. The sequence of genetic alterations occurring during the process of neoplastic and finally malignant transformation has been well characterized (3). Various molecules are involved in this process, initiated by mutation of the APC tumor suppressor gene (4). One of the best characterized signalling pathways involves $\mathrm{Wnt} / \mathrm{B}$ catenin/APC. Interestingly, there is a report on the relationship between MET and Wnt (5) that describes MET expression as an early event in the colorectal adenoma to carcinoma sequence that is controlled by the Wnt pathway. Few reports measure the expression of MET and hepatocyte growth factor/ scatter factor (HGF/SF) although Hiscox et al have reported on a small series of cases (6).

HGF has been characterized as a growth factor for hepatocytes (7-9) and inducer of cellular motility $(10,11)$. HGF/SF is the ligand for MET (12). MET was originally described as a transforming gene from a cell line treated with a chemical carcinogen (13), related to tyrosine kinase oncogenes (14). $\mathrm{HGF} / \mathrm{SF}$ levels vary in many pathologic and physiologic processes (15) and are especially important in injury, differentiation and growth. Otte et al described the functional expression of HGF and MET in colorectal cancers and suggested a paracrine mechanism of growth enhancement (16). The multiple features and properties of MET and HGF have been described in great detail in the review by Birchmeier et al (17).

The MET kinase is composed of a heterodimeric structure with an extracellular $50-\mathrm{kDa} \alpha$ chain and a transmembranous $145-\mathrm{kDa} \beta$ chain (18). HGF-MET signalling induces various processes in tumor biology (19), including proliferation (20), cell motility and invasiveness $(17,20-22)$, lumen formation and branching morphogenesis (23-26) as well as angiogenesis and stimulation of endothelial cell proliferation (27). Activating mutations of the c-met gene and increased HGF stimulation of the tumor cells may be involved in these effects. The 
existence of mis-sense mutations of the met proto-oncogene in exons 16-21 coding for the tyrosine kinase domain was demonstrated in human papillary renal, ovarian and hepatocellular carcinomas (28-33). Furthermore, a mutation in exon 14 coding for the juxtamembranous domain was detected in gastric adenocarcinoma (34). Parr et al (35) described an antagonist for $\mathrm{HGF} / \mathrm{SF}$, NK4 and showed how it reduced invasion in an in vitro assay. Herrera (36) similarly showed how HGF affected scattering in vitro using HT 29 colon carcinoma cells. Autocrine HGF stimulation was described in sarcomas and astrocytomas $(37,38)$, paracrine HGF secretion by stromal cells was observed in other cancers (39-41). In colorectal carcinomas, an overexpression of the c-met oncogene was reported $(42,43)$ and other authors obtained similar results (44-47). The present study was performed in order to quantify the expression of MET as well as HGF/SF protein expression during the colorectal adenoma-carcinoma sequence. HGF and MET protein were localized by immunofluorescence and their reactivity was detected by confocal laser scanning microscopy. The data were evaluated by quantification of the fluorescence intensity in the regions of interest (non-neoplastic vs. adenoma vs. carcinoma tissue) via computer-based image analysis.

\section{Materials and methods}

Tissues. Formalin-fixed, paraffin-embedded tissues from 41 colorectal adenomas and from 49 colorectal carcinomas from the files of the Institute of Pathology of the University of Cologne, Germany, were investigated. According to the WHO classification, 27 adenomas exhihited low-grade and 14 adenomas exhibited high-grade intraepithelial neoplasia (48). The group of colorectal carcinomas consisted of 37 intestinal type adenocarcinomas, 11 mucinous adenocarcinomas (characterized by extracellular mucin in at least $50 \%$ of the tumor area) and one solid carcinoma. Staging and grading were performed according to the TNM classification (49). Adjacent normal or reactively altered colorectal tissue was available in 64 cases (29 adenomas, 35 carcinomas).

Monoclonal antibodies and immunofluorescent double staining procedure. A rabbit polyclonal antibody (pab) C-28 directed against human MET (Santa Cruz Biotechnology, Santa Cruz, CA, USA) and a murine monoclonal antibody (mab) detecting human HGF prepared in the Laboratory of Monoclonal Antibody Production, VARI, Grand Rapids, MI, USA, (50) were applied in order to localize the respective molecules. Four $\mu \mathrm{m}$ thick sections from the tissue blocks were deparaffinized according to routine histological techniques. Non-specific protein binding was blocked by $1 \%$ bovine serum albumin (BSA) in phosphate-buffered saline (PBS) for $30 \mathrm{~min}$ at room temperature (RT). Incubation with pab C-28 $(4 \mu \mathrm{g} / \mathrm{ml}$ blocking buffer) and anti-hHGF mab $(20 \mu \mathrm{g} / \mathrm{ml}$ blocking buffer $)$ followed overnight at $4{ }^{\circ} \mathrm{C}$. Non-specific rabbit and mouse $\mathrm{IgG}$ replacing the primary antibodies were used as negative controls. After three-fold washing with PBS/0.5\% Tween-20, rhodamine-conjugated donkey anti-rabbit immunoglobulin and FITC-conjugated donkey anti-mouse immunoglobulin (Jackson Laboratory, Bar Harbour, ME, USA) diluted in blocking buffer, were incubated at RT for $30 \mathrm{~min}$. Finally, the slides were washed three times with PBS/0.5\% Tween-20 and mounted in Gel/Mount permanent aqueous mounting medium (Biomeda, Foster City, CA, USA).

Quantitative fluorescent analyses. Fluorescent analyses were performed according to previously published methods (51-53). Fluorescent-stained sections were imaged using 488- and $543-\mu \mathrm{m}$ wavelength excitation for FITC and rhodamine, respectively, using a Zeiss LSM 410 confocal laser scanning microscope (Zeiss, Oberkochen, Germany) configured with a 25-mW argon internal HeNe laser. Nomarski images were produced applying a 635 red laser. All analyses were performed with the same laser intensity, brightness, power and scan rate. Images were captured as 512x512 pixel three channel (RGB) TIFF images. The mean intensity of the red and green channels was calculated, excluding pixels with intensities below the background threshold, as determined computationally by the method of Ridler and Calvard (54). The images were analyzed using an image analysis library we have developed for the $\mathrm{R}$ statistical analysis framework (55). Using the Nomarski and H\&E images, regions of interest (ROIs) differentiating normal and tumor tissue within each image (where applicable) were manually drawn. Using these ROIs, the ratio between normal and tumor fluorescent intensity for both MET and HGF/SF staining was calculated for each patient. Two images were captured for both tumor and normal tissue (where available) for each lesion, and the mean intensities of the ROIs within these two images were averaged to achieve a final mean fluorescent intensity for each marker (MET and HGF/SF) and tissue type (normal and tumor). This ratio was then log transformed (base 2) to normalize the distribution of ratio values.

Statistical analyses. Mean expression levels of MET and $\mathrm{HGF} / \mathrm{SF}$ as estimated by fluorescent intensity were compared between the tissue types (normal vs. tumor and adenoma vs. carcinoma) using two tailed t-tests. Likewise, the logtransformed ratio of normal to tumor tissue expression of MET and HGF/SF was compared for adenomas vs. carcinomas. Expression level of these proteins, as well as log-transformed ratio of normal to tumor expression, was also compared stratifying for various clinical parameters including grade (high vs. low) and TNM stage, using t-tests (serially, where necessary). All analyses were performed using the R statistical analysis framework.

\section{Results}

Neoplastic and non-neoplastic tissue areas in the specimens were identified by histopathological evaluation of the H\&Estained images alone or Nomarski and H\&E combinations. An expression of MET protein was observed in the cytoplasm of tumor cells in most adenomas as well as carcinomas. Similarly, in normal or reactively altered epithelial and interstitial cells a fluorescent staining was present (Fig. 1A-D). On the other hand, HGF/SF staining was mostly confined to cells in the surrounding interstitial tissue, whereas only scattered tumor cells showed immunoreactivity (Fig. 1E and F).

In statistical analyses, no significant differences with regard to MET or HGF/SF expression in neoplastic and non-neoplastic 


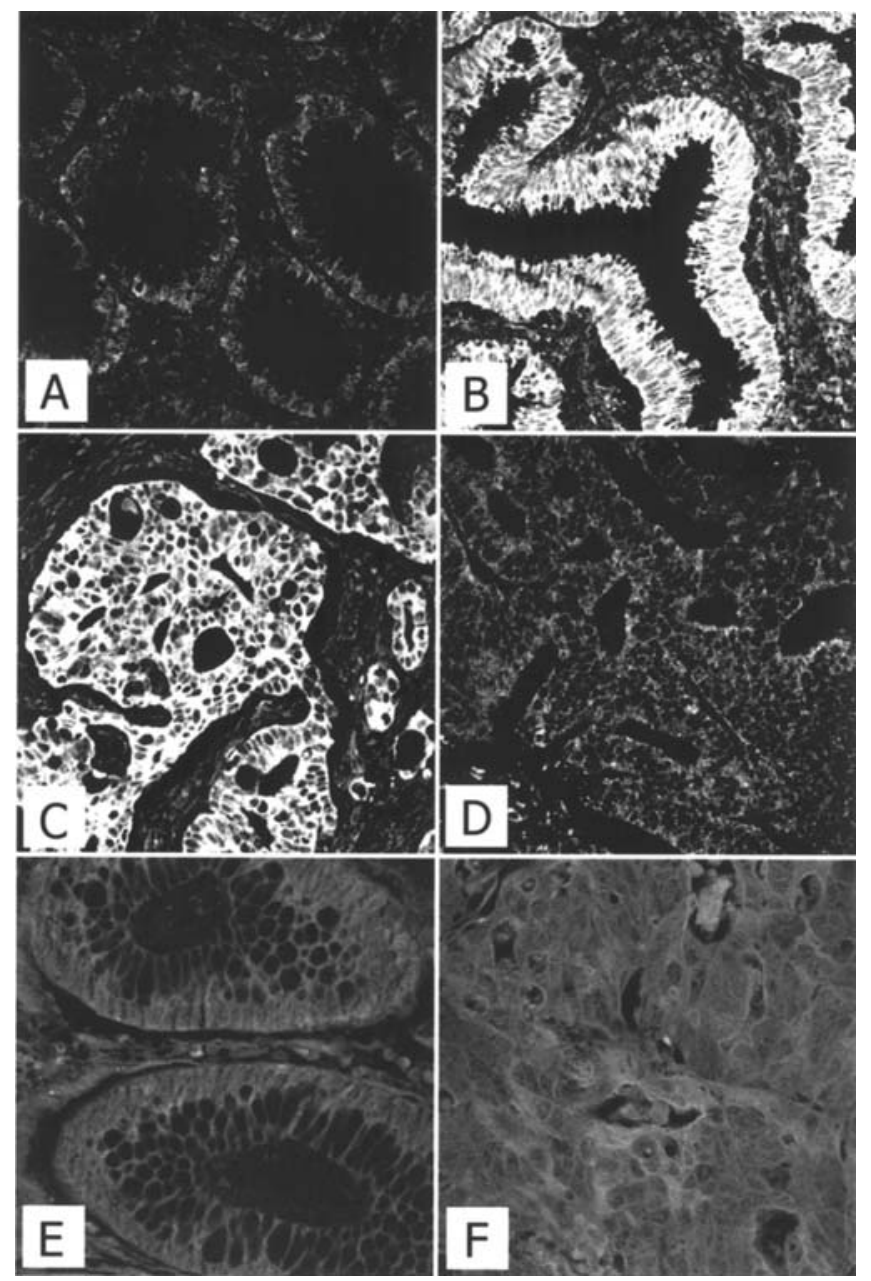

Figure 1. Normal colorectal mucosa exhibiting a faint MET expression (A) and an adenoma with high-grade intraepithelial neoplasia and strong MET immunoreactivity (B). Carcinomas showed a strong (C) or faint (D) MET positivity. HGF was mainly expressed in stromal cells in normal (E) as well as carcinomatous $(\mathrm{F})$ tissue.

epithelia were detected (Table I). Additionally, the expression levels of both molecules did not distinguish between adenomas and carcinomas. Expression of $\mathrm{HGF} / \mathrm{SF}$ in adenomatous tissue showed a statistically insignificant relationship $(\mathrm{p}=0.11)$ with low- vs. high-grade intraepithelial neoplasia, whereas all other parameters did not correlate at all.

Furthermore, fluorescence intensity detection values were correlated with histopathological parameters (Table II). The ratio of HGF expression in tumor vs. non-neoplastic tissues was predictive of high or low pTNM stage $(\mathrm{p}=0.016)$. MET expression in carcinomas showed a tendency to correlate with the grade of tumor differentiation which, however, was of borderline significance $(\mathrm{p}=0.08)$. The ratio of tumor to normal tissue expression showed a similar result $(\mathrm{p}=0.16)$. No other parameters, including $\mathrm{HGF} / \mathrm{SF}$ expression were significant, or exhibited any significant correlation with carcinoma stages or histopathological subtypes according to the WHO classification.

\section{Discussion}

MET overexpression has been described in a variety of human cancers and cell lines derived from brain (56), breast $(52,57)$, ovary $(51)$, nasopharynx $(53)$ and colorectal tissue (43). In the colorectum, multiple investigations have been completed applying different methodical approaches. In most of these studies, mRNA was isolated and measured. In an early investigation, Liu et al reported a consistent (mean sixfold) c-met mRNA overexpression in carcinomas compared to normal mucosa. Seventy percent of paired normal-tumor specimens showed a tumor to normal c-met mRNA ratio of $>4$ in their study and the expression of c-met mRNA was also enhanced in adenomas, suggesting that overexpression of this proto-oncogene may have mechanistic significance in the early stages of human colorectal carcinogenesis (42). A significantly higher c-met mRNA concentration in carcinomas compared to normal tissues was confirmed in an investigation involving 22 cases (58). Another group observed an increase of c-met gene expression from 5- to 50-fold in approximately 50\% of tumors $(n=123)$, at any stage of progression, and in $70 \%$ of liver metastases $(n=25)$. Overexpression was associated with amplification of the c-met gene in only $10 \%$ of carcinomas, but in 8 of 9 metastases examined suggesting a selective growth advantage mediated by c-met (43). Contradictory results were reported by Otte et al, who observed a reduced c-met and HGF mRNA level in liver metastases compared to primary tumors

Table I. Range, standard deviation, and means of fluorescent intensity of MET and HGF staining in neoplastic and nonneoplastic tissues.

\begin{tabular}{|c|c|c|c|c|c|c|}
\hline & \multicolumn{3}{|c|}{ MET } & \multicolumn{3}{|c|}{$\mathrm{HGF}$} \\
\hline & Range & SD & Mean & Range & SD & Mean \\
\hline Normal (surrounding carcinoma) & $43.6-162.1$ & 31.15 & 94.30 & $26.6-63.3$ & 8.70 & 34.20 \\
\hline Tumor (carcinoma) & $47.5-196.3$ & 38.16 & 111.21 & $22.8-65.4$ & 8.40 & 32.90 \\
\hline Tumor:normal ratio (carcinoma) ${ }^{\mathrm{a}}$ & $-0.8-1.6$ & 0.44 & 0.19 & $-1.0-1.2$ & 0.46 & -0.08 \\
\hline Normal (surrounding adenoma) & $53.2-190.7$ & 39.48 & 109.50 & $22.2-48.0$ & 6.40 & 31.60 \\
\hline Tumor (adenoma) & $47.7-197.3$ & 36.03 & 116.30 & $23.3-41.7$ & 4.30 & 30.30 \\
\hline Tumor:normal ratio (adenoma) ${ }^{\mathrm{a}}$ & $-0.7-1.4$ & 0.48 & 0.16 & $-0.9-0.7$ & 0.34 & -0.05 \\
\hline
\end{tabular}

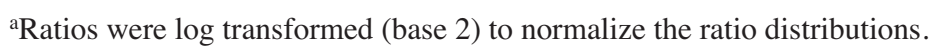


Table II. Means and standard deviations of fluorescent intensity of MET and HGF staining in tumor tissues and logtransformed tumor:normal ratio of staining intensity within histopathological subgroups.

\begin{tabular}{|c|c|c|c|c|c|c|c|c|}
\hline & \multicolumn{4}{|c|}{ MET } & \multicolumn{4}{|c|}{ HGF } \\
\hline & $\begin{array}{l}\text { Tumor } \\
\text { mean }\end{array}$ & $\begin{array}{c}\text { Tumor } \\
\text { SD }\end{array}$ & $\begin{array}{c}\log \mathrm{T}: \mathrm{N} \\
\text { mean }\end{array}$ & $\begin{array}{l}\log T: N \\
\text { SD }\end{array}$ & $\begin{array}{l}\text { Tumor } \\
\text { mean }\end{array}$ & $\begin{array}{l}\text { Tumor } \\
\text { SD }\end{array}$ & $\begin{array}{c}\log \mathrm{T}: \mathrm{N} \\
\text { mean }\end{array}$ & $\begin{array}{c}\log T: N \\
\text { SD }\end{array}$ \\
\hline \multicolumn{9}{|l|}{ Carcinomas } \\
\hline \multicolumn{9}{|l|}{ Grade } \\
\hline 1 and 2 & 112.8 & 36.8 & 0.24 & 0.42 & 32.0 & 8.3 & -0.12 & 0.43 \\
\hline 3 & 105.7 & 44.2 & -0.04 & 0.45 & 35.5 & 8.5 & 0.08 & 0.55 \\
\hline \multicolumn{9}{|l|}{ pTNM stage } \\
\hline $\mathrm{I}$ & 103.3 & 38.9 & 0.16 & 0.28 & 34.9 & 9.0 & 0.11 & 0.34 \\
\hline II & 111.3 & 39.1 & 0.05 & 0.46 & 32.0 & 10.3 & -0.13 & 0.60 \\
\hline III & 121.3 & 37.6 & 0.43 & 0.61 & 32.3 & 5.2 & -0.26 & 0.25 \\
\hline IV & 110.2 & 20.6 & 0.25 & 0.31 & 31.8 & 6.5 & -0.19 & 0.49 \\
\hline \multicolumn{9}{|l|}{ WHO subtypes } \\
\hline Tubular/papillary & 112.8 & 36.8 & 0.24 & 0.42 & 32.0 & 8.3 & -0.12 & 0.43 \\
\hline Mucinous & 102.4 & 45.6 & -0.04 & 0.45 & 35.1 & 8.7 & 0.08 & 0.55 \\
\hline \multicolumn{9}{|l|}{ Adenomas } \\
\hline Low-grade intraepithelial neoplasia & 116.6 & 31.0 & 0.15 & 0.44 & 30.5 & 4.5 & -0.01 & 0.36 \\
\hline High-grade intraepithelial neoplasia & 115.8 & 46.2 & 0.18 & 0.56 & 29.9 & 4.22 & -0.09 & 0.32 \\
\hline
\end{tabular}

and normal mucosa, while the extent of protein expression detected immunohistochemically correlated with the mRNA expression (16). Hiscox et al reported an overexpression of c-met RNA in all cases $(\mathrm{n}=21)$ under study, whereas only $75 \%$ displayed up-regulation of the protein (6). On the other hand, Southern blot analysis and RT-PCR revealed an amplification of the c-met gene in $12 \%$ of colorectal cancer samples $(n=43)$, and an overexpression in $30 \%$ only. Significant associations with clinical parameters and survival were not observed (59). In a previous investigation involving normal epithelium from eight patients and 36 primary colorectal carcinomas, a significantly higher number of c-met mRNA copies were detected in the latter. Furthermore, c-met mRNA copy number correlated with the depth of invasion as well as being enhanced in $\mathrm{pN} 1 / \mathrm{pN} 2$ stage patients compared to pN0 patients (46). A published study using tissue microarray analysis of 110 colorectal tissues by phosphor image analysis after c-met mRNA in situ hybridisation showed a 2.5 -fold increase in carcinomas compared to normal tissues (60).

Other studies have measured MET protein by Western blotting and immunohistochemistry. Paraffin-embedded tumor samples from 86 patients with colon cancers in Dukes' B and C stages indicated a significant up-regulation of the MET protein in stage C vs. stage B carcinomas (44). In an immunohistochemical investigation on frozen tissue sections of normal mucosa $(n=6)$, colorectal adenomas $(n=6)$ and carcinomas $(n=54)$ an increase of semi-quantitatively evaluated MET protein expression along the adenoma-carcinoma sequence was reported (47). In the same study, an enhancement of HGF mRNA expression in carcinomas vs. normal tissues was additionally observed, and HGF protein expression was detected in cells present within the tumor stroma. In a prognostic study using tissue microarrays, an association between MET expression and survival probability in TNM stage II patients was not observed (61).

In the present study, we utilized an immunohistochemical double-staining method in order to co-localize MET and HGF in normal and neoplastic colorectal tissues. By immunofluorescent double-labelling, both molecules were detected and quantified by confocal laser microscopy. According to our data, and in contrast to numerous studies measuring c-met mRNA, expression differences between normal mucosa, adenomas and carcinomas were not significant. Analogously, the grade of intraepithelial neoplasia of adenomas as well as the histopathological subtype, pTNM staging and grading of carcinomas did not correlate with differences regarding the MET protein levels. HGF did not exhibit significant associations with these clinico-pathological parameters. However, the ratio of HGF expression in tumor vs. non-neoplastic epithelia is a predictive parameter for high vs. low pTNM stage.

Our data result from the first quantitative evaluation of MET and HGF proteins in the colorectal adenoma-carcinoma sequence, for which previous studies reported contradictory results $(44,47)$. When interpreting these data, several aspects regarding HGF-MET interactions are of interest. Whereas MET was expressed in cells of epithelial origin, HGF expression was mostly confined to mesenchymal cells suggesting paracrine effects on the tumor cells (16), as confirmed by our results. On the other hand, HGF bioactivity may be controlled by tumor-cell derived factors such as HGF activator (HGFA) and its inhibitor HGFA inhibitor type 1 (HAI-1), which are both detected in colorectal mucosa as well as neoplasms (45). 
Therefore, it is tempting to speculate that HGF-MET interactions may depend on various other factors involved in their regulation.

With regard to previous data describing an overexpression of c-met mRNA, the turnover of MET protein in colorectal neoplasms should be included in further studies. In addition, in other organ systems the level of MET protein expression also exhibits differences between normal epithelia and their respective neoplasms. Applying the same immunofluorescent staining and quantitative analysis by confocal laser microscopy as in the present study, ovarian neoplasms exhibited a stronger staining compared to ovarian surface epithelium (51), whereas nasopharyngeal carcinomas showed an intermediate MET protein level as compared with either squamous cell or respiratory epithelium (53). Furthermore, the degree of MET tyrosine phosphorylation may represent a decisive factor in this context, since highly metastatic colorectal carcinoma cell lines expressed a constitutively tyrosine phosphorylated MET, whereas cell lines with a low metastatic potential did not (62). In colorectal cancer cell subclones with an only modestly reduced MET expression, a $60-90 \%$ reduction in basal MET autophosphorylation and kinase activity correlated with significantly reduced in vitro and in vivo growth rates of these cells (63). Our data and these observations indicate that functional aspects and not only the level of protein expression determine the biological role of HGF-MET interactions during colorectal carcinogenesis. Furthermore, interactions of MET with tyrosine-phosphorylated B-catenin may exert influences on $\mathrm{T}$ cell factor (tcf) activity and transcriptional target genes such as cyclin D1, c-myc and UPAR (62). The significance of HGF expression in this analysis of colonic tumors and adenomas also suggests that an adjuvant therapy either as an antibody or ligand analogue that inactivates or targets the Met receptor or neutralizes the natural ligand $\mathrm{HGF} / \mathrm{SF}$ could be of therapeutic benefit.

\section{Acknowledgements}

We thank Bree Buckner and Eric A. Hudson, Laboratory of Analytical, Cellular, and Molecular Microscopy, VARI, as well as Stephanie Landsberg, Institute of Pathology, University of Cologne, for their excellent technical assistance.

\section{References}

1. Jass JR, Young J and Leggett BA: Evolution of colorectal cancer: change of pace and change of direction. J Gastroenterol Hepatol 17: 17-26, 2002.

2. Muto T, Bussey HJ and Morson BC: The evolution of cancer of the colon and rectum. Cancer 36: 2251-2270, 1975.

3. Vogelstein B, Fearon ER, Hamilton SR, Kern SE, Preisinger AC, Leppert M, Nakamura Y, White R, Smits AM and Bos JL: Genetic alterations during colorectal-tumor development. N Engl J Med 319: 525-532, 1988.

4. Lamlum H, Papadopoulou A, Ilyas M, Rowan A, Gillet C, Hanby A, Talbot I, Bodmer W and Tomlinson I: APC mutations are sufficient for the growth of early colorectal adenomas. Proc Natl Acad Sci USA 97: 2225-2228, 2000.

5. Boon EM, van der Neut R, van de Wetering M, Clevers $H$ and Pals ST: Wnt signaling regulates expression of the receptor tyrosine kinase met in colorectal cancer. Cancer Res 62: 5126-5128, 2002.

6. Hiscox SE, Hallett MB, Puntis MC, Nakamura T and Jiang WG: Expression of the HGF/SF receptor, c-met, and its ligand in human colorectal cancers. Cancer Invest 15: 513-521, 1997.
7. Nakamura T, Nawa K, Ichihara A, Kaise $\mathrm{N}$ and Nishino T: Purification and subunit structure of hepatocyte growth factor from rat platelets. FEBS Lett 224: 311-316, 1987.

8. Gohda E, Tsubouchi H, Nakayama H, Hirono S, Sakiyama O, Takahashi K, Miyazaki H, Hashimoto S and Daikuhara Y: Purification and partial characterization of hepatocyte growth factor from plasma of a patient with fulminant hepatic failure. J Clin Invest 81: 414-419, 1988.

9. Zarnegar R and Michalopoulos G: Purification and biological characterization of human hepatopoietin $\mathrm{A}$, a polypeptide growth factor for hepatocytes. Cancer Res 49: 3314-3320, 1989.

10. Weidner KM, Arakaki N, Hartmann G, Vandekerckhove J, Weingart S, Rieder H, Fonatsch C, Tsubouchi H, Hishida T, Daikuhara Y, et al: Evidence for the identity of human scatter factor and human hepatocyte growth factor. Proc Natl Acad Sci USA 88: 7001-7005, 1991.

11. Naldini L, Weidner KM, Vigna E, Gaudino G, Bardelli A, Ponzetto C, Narsimhan RP, Hartmann G, Zarnegar R, Michalopoulos GK, et al: Scatter factor and hepatocyte growth factor are indistinguishable ligands for the MET receptor. EMBO J 10: 2867-2878, 1991.

12. Bottaro DP, Rubin JS, Faletto DL, Chan AM, Kmiecik TE, Vande Woude GF and Aaronson SA: Identification of the hepatocyte growth factor receptor as the c-met proto-oncogene product. Science 251: 802-804, 1991.

13. Cooper CS, Park M, Blair DG, Tainsky MA, Huebner K, Croce CM and Vande Woude GF: Molecular cloning of a new transforming gene from a chemically transformed human cell line. Nature 311: 29-33, 1984.

14. Dean M, Park M, Le Beau MM, Robins TS, Diaz MO, Rowley JD, Blair DG and Vande Woude GF: The human met oncogene is related to the tyrosine kinase oncogenes. Nature 318: 385-388, 1985

15. Funakoshi $\mathrm{H}$ and Nakamura $\mathrm{T}$ : Hepatocyte growth factor: from diagnosis to clinical applications. Clin Chim Acta 327: 1-23, 2003.

16. Otte JM, Schmitz F, Kiehne K, Stechele HU, Banasiewicz T, Krokowicz P, Nakamura T, Folsch UR and Herzig K: Functional expression of HGF and its receptor in human colorectal cancer. Digestion 61: 237-246, 2000.

17. Birchmeier C, Birchmeier W, Gherardi E and Vande Woude GF: Met, metastasis, motility and more. Nat Rev Mol Cell Biol 4: 915-925, 2003.

18. Giordano S, Di Renzo MF, Narsimhan RP, Cooper CS, Rosa C and Comoglio PM: Biosynthesis of the protein encoded by the c-met proto-oncogene. Oncogene 4: 1383-1388, 1989.

19. Jeffers M, Rong S and Woude GF: Hepatocyte growth factor/ scatter factor-Met signaling in tumorigenicity and invasion/ metastasis. J Mol Med 74: 505-513, 1996.

20. Tajima H, Matsumoto $\mathrm{K}$ and Nakamura T: Regulation of cell growth and motility by hepatocyte growth factor and receptor expression in various cell species. Exp Cell Res 202: 423-431, 1992.

21. Rong S, Segal S, Anver M, Resau JH and Vande Woude GF: Invasiveness and metastasis of NIH 3 T3 cells induced by Methepatocyte growth factor/scatter factor autocrine stimulation. Proc Natl Acad Sci USA 91: 4731-4735, 1994.

22. Jeffers M, Rong S, Anver M and Vande Woude GF: Autocrine hepatocyte growth factor/scatter factor-Met signaling induces transformation and the invasive/metastastic phenotype in C127 cells. Oncogene 13: 853-856, 1996.

23. Montesano R, Schaller G and Orci L: Induction of epithelial tubular morphogenesis in vitro by fibroblast-derived soluble factors. Cell 66: 697-711, 1991.

24. Tsarfaty I, Resau JH, Rulong S, Keydar I, Faletto DL and Vande Woude GF: The met proto-oncogene receptor and lumen formation. Science 257: 1258-1261, 1992.

25. Johnson M, Koukoulis G, Matsumoto K, Nakamura T and Iyer A: Hepatocyte growth factor induces proliferation and morphogenesis in nonparenchymal epithelial liver cells. Hepatology 17: 1052-1061, 1993.

26. Zhang YW and Vande Woude GF: HGF/SF-met signaling in the control of branching morphogenesis and invasion. J Cell Biochem 88: 408-417, 2003.

27. Bussolino F, Di Renzo MF, Ziche M, Bocchietto E, Olivero M, Naldini L, Gaudino G, Tamagnone L, Coffer A and Comoglio PM: Hepatocyte growth factor is a potent angiogenic factor which stimulates endothelial cell motility and growth. J Cell Biol 119: 629-641, 1992. 
28. Jeffers M, Schmidt L, Nakaigawa N, Webb CP, Weirich G, Kishida T, Zbar B and Vande Woude GF: Activating mutations for the met tyrosine kinase receptor in human cancer. Proc Natl Acad Sci USA 94: 11445-11450, 1997.

29. Schmidt L, Duh FM, Chen F, Kishida T, Glenn G, Choyke P, Scherer SW, Zhuang Z, Lubensky I, Dean M, Allikmets R, Chidambaram A, Bergerheim UR, Feltis JT, Casadevall C, Zamarron A, Bernues M, Richard S, Lips CJ, Walther MM, Tsui LC, Geil L, Orcutt ML, Stackhouse T, Zbar B, et al: Germline and somatic mutations in the tyrosine kinase domain of the MET proto-oncogene in papillary renal carcinomas. Nat Genet 16: 68-73, 1997

30. Jeffers M, Fiscella M, Webb CP, Anver M, Koochekpour S and Vande Woude GF: The mutationally activated Met receptor mediates motility and metastasis. Proc Natl Acad Sci USA 95: 14417-14422, 1998.

31. Olivero M, Valente G, Bardelli A, Longati P, Ferrero N, Cracco C, Terrone C, Rocca-Rossetti S, Comoglio PM and Di Renzo MF: Novel mutation in the ATP-binding site of the MET oncogene tyrosine kinase in a HPRCC family. Int J Cancer 82: 640-643, 1999.

32. Park WS, Dong SM, Kim SY, Na EY, Shin MS, Pi JH, Kim BJ, Bae JH, Hong YK, Lee KS, Lee SH, Yoo NJ, Jang JJ, Pack S, Zhuang Z, Schmidt L, Zbar B and Lee JY: Somatic mutations in the kinase domain of the Met/hepatocyte growth factor receptor gene in childhood hepatocellular carcinomas. Cancer Res 59: 307-310, 1999.

33. Schmidt L, Junker K, Nakaigawa N, Kinjerski T, Weirich G, Miller M, Lubensky I, Neumann HP, Brauch H, Decker J, Vocke C, Brown JA, Jenkins R, Richard S, Bergerheim U, Gerrard B, Dean M, Linehan WM and Zbar B: Novel mutations of the MET proto-oncogene in papillary renal carcinomas. Oncogene 18: 2343-2350, 1999.

34. Lee JH, Han SU, Cho H, Jennings B, Gerrard B, Dean M, Schmidt L, Zbar B and Vande Woude GF: A novel germ line juxtamembrane Met mutation in human gastric cancer. Oncogene 19: 4947-4953, 2000.

35. Parr C, Hiscox S, Nakamura T, Matsumoto K and Jiang WG: $\mathrm{Nk} 4$, a new HGF/SF variant, is an antagonist to the influence of $\mathrm{HGF} / \mathrm{SF}$ on the motility and invasion of colon cancer cells. Int $\mathrm{J}$ Cancer 85: 563-570, 2000.

36. Herrera R: Modulation of hepatocyte growth factor-induced scattering of HT29 colon carcinoma cells. Involvement of the MAPK pathway. J Cell Sci 111: 1039-1049, 1998.

37. Rong S, Jeffers M, Resau JH, Tsarfaty I, Oskarsson M and Vande Woude GF: Met expression and sarcoma tumorigenicity. Cancer Res 53: 5355-5360, 1993.

38. Chattopadhyay N, Butters RR and Brown EM: Agonists of the retinoic acid- and retinoid X-receptors inhibit hepatocyte growth factor secretion and expression in U87 human astrocytoma cells. Brain Res Mol Brain Res 87: 100-108, 2001.

39. Seslar SP, Nakamura T and Byers SW: Regulation of fibroblast hepatocyte growth factor/scatter factor expression by human breast carcinoma cell lines and peptide growth factors. Cancer Res 53: 1233-1238, 1993.

40. Nakamura T, Matsumoto K, Kiritoshi A and Tano Y: Induction of hepatocyte growth factor in fibroblasts by tumor-derived factors affects invasive growth of tumor cells: in vitro analysis of tumor-stromal interactions. Cancer Res 57: 3305-3313, 1997.

41. Jiang W, Hiscox S, Matsumoto K and Nakamura T: Hepatocyte growth factor/scatter factor, its molecular, cellular and clinical implications in cancer. Crit Rev Oncol Hematol 29: 209-248, 1999.

42. Liu C, Park M and Tsao MS: Overexpression of c-met protooncogene but not epidermal growth factor receptor or c-erbB-2 in primary human colorectal carcinomas. Oncogene 7: 181-185, 1992.

43. Di Renzo MF, Olivero M, Giacomini A, Porte H, Chastre E, Mirossay L, Nordlinger B, Bretti S, Bottardi S, Giordano S, et al: Overexpression and amplification of the met/HGF receptor gene during the progression of colorectal cancer. Clin Cancer Res 1 : $147-154,1995$

44. Fazekas K, Csuka O, Koves I, Raso E and Timar J: Experimental and clinicopathologic studies on the function of the HGF receptor in human colon cancer metastasis. Clin Exp Metastasis 18: 639-649, 2000.
45. Kataoka $\mathrm{H}$, Hamasuna $\mathrm{R}$, Itoh $\mathrm{H}$, Kitamura $\mathrm{N}$ and Koono $\mathrm{M}$ : Activation of hepatocyte growth factor/scatter factor in colorectal carcinoma. Cancer Res 60: 6148-6159, 2000.

46. Takeuchi H, Bilchik A, Saha S, Turner R, Wiese D, Tanaka M, Kuo C, Wang HJ and Hoon DS: c-MET expression level in primary colon cancer: a predictor of tumor invasion and lymph node metastases. Clin Cancer Res 9: 1480-1488, 2003.

47. Wielenga VJ, van der Voort R, Taher TE, Smit L, Beuling EA, van Krimpen C, Spaargaren M and Pals ST: Expression of c-Met and heparan-sulfate proteoglycan forms of CD44 in colorectal cancer. Am J Pathol 157: 1563-1573, 2000.

48. Hamilton SR and Aaltonen LA: World Health Organization classification of tumours. Pathology and genetics of tumours of the digestive system. IARC, Lyon, 2000.

49. Sobin LH and Wittekind C: TNM classification of malignant tumours. 6th edition. Wiley-Liss, New York, 2002.

50. Cao B, Su Y, Oskarsson M, Zhao P, Kort EJ, Fisher RJ, Wang LM and Vande Woude GF: Neutralizing monoclonal antibodies to hepatocyte growth factor/scatter factor (HGF/SF) display antitumor activity in animal models. Proc Natl Acad Sci USA 98: 7443-7448, 2001.

51. Huntsman D, Resau JH, Klineberg E and Auersperg N: Comparison of c-met expression in ovarian epithelial tumors and normal epithelia of the female reproductive tract by quantitative laser scan microscopy. Am J Pathol 155: 343-348, 1999.

52. Tsarfaty I, Alvord WG, Resau JH, Altstock RT, Lidereau R, Bieche I, Bertrand F, Horev J, Klabansky RL, Keydar I and Vande Woude GF: Alteration of Met protooncogene product expression and prognosis in breast carcinomas. Anal Quant Cytol Histol 21: 397-408, 1999.

53. Qian CN, Guo X, Cao B, Kort EJ, Lee CC, Chen J, Wang LM, Mai WY, Min HQ, Hong MH, Vande Woude GF, Resau JH and Teh BT: Met protein expression level correlates with survival in patients with late-stage nasopharyngeal carcinoma. Cancer Res 62: 589-596, 2002.

54. Ridler T and Calvard S: Picture thresholding using an iterative selection method. IEEE Trans. on Systems, Man, and Cybernetics. SMC 8: 630-632, 1978.

55. Ihaka R and Gentleman RR: A language for data analysis and graphics. J Comp Graph Statistics 5: 299-314, 1996.

56. Jung W, Castren E, Odenthal M, Vande Woude GF, Ishii T, Dienes HP, Lindholm D and Schirmacher P: Expression and functional interaction of hepatocyte growth factor-scatter factor and its receptor c-met in mammalian brain. J Cell Biol 126: 485-494, 1994.

57. Altstock RT, Stein GY, Resau JH and Tsarfaty I: Algorithms for quantitation of protein expression variation in normal versus tumor tissue as a prognostic factor in cancer: Met oncogene expression, and breast cancer as a model. Cytometry 41: 155-165, 2000.

58. Fujita S and Sugano K: Expression of c-met proto-oncogene in primary colorectal cancer and liver metastases. Jpn J Clin Oncol 27: 378-383, 1997.

59. Umeki K, Shiota G and Kawasaki H: Clinical significance of c-met oncogene alterations in human colorectal cancer. Oncology 56: 314-321, 1999.

60. Jubb AM, Landon TH, Burwick J, Pham TQ, Frantz GD, Cairns B, Quirke P, Peale FV and Hillan KJ: Quantitative analysis of colorectal tissue microarrays by immunofluorescence and in situ hybridization. J Pathol 200: 577-588, 2003.

61. Resnick MB, Routhier J, Konkin T, Sabo E and Pricolo VE: Epidermal growth factor receptor, c-MET, beta-catenin, and p53 expression as prognostic indicators in stage II colon cancer: A tissue microarray study. Clin Cancer Res 10: 3069-3075, 2004.

62. Herynk MH, Tsan R, Radinsky R and Gallick GE: Activation of c-Met in colorectal carcinoma cells leads to constitutive association of tyrosine-phosphorylated beta-catenin. Clin Exp Metastasis 20: 291-300, 2003.

63. Herynk MH, Stoeltzing O, Reinmuth N, Parikh NU, Abounader R, Laterra J, Radinsky R, Ellis LM and Gallick GE: Down-regulation of c-Met inhibits growth in the liver of human colorectal carcinoma cells. Cancer Res 63: 2990-2996, 2003. 